\title{
Entrevista com Carlos Berriel
}

Fernando Breda*

Em meados de 2020, o Brasil já somava meses de quarentena em decorrência da pandemia de Covid-19. Em respeito aos protocolos de segurança, a entrevista foi feita por Skype. A despeito de recorrentes falhas de conexão, a conversa se deu por quase quatro horas.

Carlos Berriel é professor de Teoria e História Literária na Universidade Estadual de Campinas. Há alguns anos tem se dedicado ao estudo e tradução de utopias. Suas primeiras pesquisas acadêmicas, no entanto, se debruçaram sobre outro assunto: o Modernismo paulista. Escreveu uma dissertação de mestrado sobre o romance Macunaíma, de Mário de Andrade, e, no doutorado, analisou a figura de Paulo Prado, um dos mentores da Semana de Arte Moderna de 1922. Nesses trabalhos, orientados por Roberto Schwarz, Berriel procurou situar o chão histórico e ideológico sobre o qual o movimento modernista estava situado. Na pena do crítico, despontou, então, um movimento artístico de relação bastante significativa com as oligarquias cafeeiras paulistas. Algo um tanto distante das visões mais consagradoras do movimento, que muitas vezes o qualificam como um momento da cultura brasileira de ruptura estético-social com um certo marasmo político-cultural predominante no país até então.

A ideia desta entrevista era retomar esses estudos, os quais Berriel tem abordado apenas ocasionalmente desde sua defesa

* Universidade de Campinas (UNICAMP). Mestre em Teoria e História Literária. Bolsista Capes. 
de doutorado. No mais, em 2022, completam-se cem anos da realização da Semana de Arte Moderna. As celebrações já estão agendadas. Imagino que retomar estudos que reconheçam a força do movimento, mas também procurem pensá-lo à luz de suas contradições e vinculações de classe, possa ser também uma forma de celebração da efeméride.

\section{***}

Fernando Breda: Passados mais de 25 anos de seu doutorado, você retornou à questão do Modernismo em texto publicado na Folha de S. Paulo. ${ }^{1}$ De novo sua hipótese foi alvo de polêmica. O que te levou a voltar ao tema depois de tanto tempo?

Carlos Berriel: Eu sou um velho amigo do Ruy Castro, e ele me disse há uns cinco anos que vinha pensado em escrever um livro, digamos assim, tocado por uma passagem do meu estudo sobre o Paulo Prado: ${ }^{2}$ quando falo que o Modernismo precisou desvalorizar a cultura que se produzia no Rio de Janeiro por conta da disputa política da oligarquia paulista com o Rio.

O Rio de Janeiro era, de fato, a capital do Brasil desde o Império - administrativamente, até antes, quando Pombal transferiu a capital de Salvador para lá. Assim, a partir da vinda da família real, a cidade se constituiu efetivamente na metrópole cultural brasileira, porque era também uma metrópole política. O Rio conseguia reunir e atrair a produção cultural do Brasil como um todo: era lá que os cearenses, os pernambucanos, gaúchos etc. ganhavam projeção nacional. No Rio de Janeiro, o que era regional transformava-se em nacional. Isso se chama síntese.

\footnotetext{
$\overline{1}$ Resenha ao último livro de Ruy Castro. CASTRO, Ruy. Metrópole à beira-mar - o Rio moderno dos anos 20. São Paulo, Companhia das Letras, 2019.

2 BERRIEL, Carlos. Tietê, Tejo, Sena. Campinas: Editora da UNICAMP, 2013.
} 
E é contra isso que o Modernismo se insurge: a oligarquia paulista queria que São Paulo se transformasse justamente na metrópole brasileira. Aquele momento final dos anos 1910 e 1920 era um momento de grande disputa nesse sentido.

Ruy Castro se interessou muito por essa passagem e considerando uma "sacanagem" a leitura, muito uspiana e modernista, do Rio de Janeiro como um deserto com múmias com cartão da Academia [Brasileira de Letras], decidiu mostrar que não era assim. E ele escreveu esse livro Metrópole à beira-mar. Eu li o livro e fiquei até surpreso: eu sabia que não era o que os modernistas falaram, mas ele mostra um Rio muito vibrante.

A Folha me pediu uma resenha, e eu escrevi minha resenha dizendo isso; aí um cara lá, que eu nem sei quem é...

Fernando Breda: Um biógrafo do Mário de Andrade. ${ }^{3}$

Carlos Berriel: Que não conhece nada do Mário de Andrade. Fiquei pasmo. Mas, enfim, o sujeito me vem com uma agressão de quem tem uma visão muito secundarista, longe do patamar que o tema já alcançou no debate. Falou em classe média, algo como amiguinhos que se reúnem e fazem a Semana de Arte Moderna! Não entendeu nada. O desejo de virar um nome no debate sobre o Modernismo foi muito grande. Fui obrigado a responder. Aquilo é uma versão muito tosca do idealismo que costuma organizar os estudos sobre o Modernismo. Idealismo no sentido de tomar que as ideias nascem das ideias. Bom, eu acho que não! E as pessoas que escreveram os melhores trabalhos, mesmo aqueles dos quais eu discordo, também acham que não. As ideias não

3 Jason Tércio, autor de Em busca da alma brasileira - biografia de Mário de Andrade. Rio de Janeiro: Estação Brasil, 2019. 
nascem das ideias, as ideias nascem de um complexo históricosocial. Elas mesmas fazem parte desse complexo, mobilizam, organizam, mas também são produzidas por ele. O que eu procurei demonstrar no meu trabalho acadêmico e nesses artigos é que o Modernismo é porrada. Tem uma relação de classe muito forte, explícita.

O Romantismo brasileiro, por exemplo, não teve um grande empresário do açúcar. No caso do Modernismo, foi uma relação direta com a sociedade do café. Isso foi uma coisa extremamente interessante, com repercussões até hoje.

Fernando Breda: Até onde entendo, então, na sua leitura do Modernismo existe uma preocupação em retirá-lo de uma visão de um grupo que estaria pairando sobre um chão histórico vazio. Como um colega disse em outro momento: você jogou café nesse chope idealista. Em que medida essa vinculação com a elite paulista-cafeeira é possível de se ver nas principais obras, especialmente em Macunaíma (1928)?

Carlos Berriel: Bom, sobre Macunaíma: é uma obra gigantesca. Ele está entre os grandes romances brasileiros por sua capacidade de formalizar tensões históricas fundamentais da sociedade brasileira.

Eu acho que Macunaíma é um romance que faz parte desse conglomerado de obras e de autores que buscavam colocar São Paulo culturalmente no centro do Brasil. Mas Macunaíma é diferente num aspecto importante, por exemplo, do trabalho do Paulo Prado (ao qual ele é muito vinculado - inclusive, Mário diz explicitamente: "eu escrevi isso aqui de olho no trabalho do 
Paulo Prado" e dedica o romance a Paulo Prado): o inimigo não é exatamente o mesmo.

Paulo Prado é "inimigo do Brasil", digamos assim. Ele é um ideólogo de uma hegemonia do café, o que quer dizer uma hegemonia paulista - o que, em si, também tem problema porque havia café no Rio, em Minas... mas não vamos discutir isso agora. Para simplificar, fiquemos com "cafeicultura paulista". O que o Paulo Prado objetiva nos trabalhos dele é uma alteração na organização do país de forma a dar um status político a São Paulo diferente do Brasil. Resumidamente, transformar o Brasil numa colônia da "metrópole São Paulo". Ou seja, os demais estados e províncias subordinadas a um centro organizador, hegemônico, e também sintetizador política e economicamente.

O que, inclusive, já estava acontecendo na República Velha a partir do Convênio de Taubaté, quando foi criado um sistema no qual todos os estados ficaram subordinados economicamente ao café.

Em Retrato do Brasil (1928) e Paulística (1925), ${ }^{4}$ Prado está em briga com o Brasil, de forma a colocar o resto do país subordinado a São Paulo por um argumento de ordem racial. Para ele, o Brasil seria composto de uma mescla de raças que deu errado: o brasileiro seria uma sub-raça inferior, enquanto o paulista seria uma mescla racial superior. Para tanto, ele vai buscar argumentos na Alemanha, na França e em experimentos alemães no sul da África.

Ele usa esses argumentos para justificar a implantação no Brasil de um regime colonial. Um pouco como a África do Sul, que eu acho que é um grande paralelo, onde havia um tipo de capitalismo

4 PRADO, Paulo. Província \& Nação - Paulística - Retrato do Brasil. Rio de Janeiro: José Olympio, 1972. 
em que a metrópole e a colônia dividiam o mesmo território. Não é que o modelo dele fosse a África do Sul, não existia o apartheid ainda, mas a sua ideia configura um apartheid: ou seja, metrópole e colônia no mesmo território, porém com uma legislação de tipo colonial.

E aí há um ponto importante: ele vê a oligarquia do café como - ele não usa essa expressão, mas, enfim... - como uma classe capaz de possuir um país. Isso é muito significativo. É isso, inclusive, o que dá a importância ao Modernismo, porque está ligado a uma classe que quis o país para si. Paulo Prado que, resumindo, é o grande espírito organizador da Semana de 1922 e do Modernismo - não é o maior intelectual, mas é o grande organizador - ele queria o Brasil para a sua classe.

Ocorre que a burguesia brasileira, de segunda ou terceira classe, historicamente nunca quis o país para si como as burguesias clássicas - inglesa, francesa etc. -, ela quer apenas ser sócia da exploração estrangeira em seu próprio país. É por isso que o Modernismo é importante. Esta é a grande contradição: querer modernamente a autonomia nacional, ao mesmo tempo que propõe uma forma grotesca de colonização do país.

Feito esse aspecto, falemos de Mário de Andrade, que é o grande intelectual do Modernismo, não só o maior escritor. E quando eu falo Modernismo, eu penso principalmente em Modernismo paulista. O Macunaíma é diferente do Paulo Prado, não como ponto de partida político-social, mas quanto ao foco, que é mais particularizado.

Todo romance tem um inimigo e se constitui sempre como uma disputa. Nós temos Macunaíma, o herói: uma construção sintética operada por uma consciência, no caso paulista, que 
procura costurar mitos regionais e dar a ele uma dimensão nacional. A transposição do regional, do folclórico, do índio, do mito indígena etc. se transforma em uma entidade nacional no processo de síntese literária de Mário de Andrade.

Macunaíma é um mito indígena, mas ao mesmo tempo, nos primeiros capítulos, seu personagem vai sendo composto de muitos elementos que não são apenas indígenas, mas de várias regiões do país. Nesse movimento, ele vai ganhando consistência de um herói alegórico: uma alegoria do Brasil; porém, não pronta, uma alegoria em construção.

Acontece que, no andamento do romance, ele ganha, pelo jogo genial do Mário de Andrade, uma missão que não tinha no começo: recuperar a pedra Muiraquitã - tudo isso é mitologia indígena -, que adquire no romance a simbologia de hipótese/ possibilidade de criação de uma civilização brasileira.

Nisso, o Mário de Andrade está de acordo com as teorias históricas do Herder, Spengler e Keyserling - era essa tríade de filósofos alemães que Mário tinha na cabeça. Isto é, a ideia de que na História a cultura seria espontânea, ligada à natureza, não urbana e não moderna. E à medida que os povos constituem uma cultura, essa cultura vai naturalmente se transformando em civilização. Assim, todos os povos teriam cultura, mas nem todos teriam civilização. A cultura iria se sofisticando e se tornando inteligente à medida que se afasta da natureza pelo desenvolvimento da técnica. De modo que ela vai, então, perdendo o vínculo vital, instintivo, irracional, intuitivo com a natureza que lhe deu origem, e vai se desenvolvendo, se tornando inteligente, cerebral, e, assim, vai perdendo a alma.

O desenvolvimento da técnica levaria à urbanização, fazendo 
com que a cidade se torne uma metrópole - o filme Metrópolis de Fritz Lang é baseado em Spengler. Na grande cidade, a cultura torna-se morta porque a sua alma morreu, ela é só razão e não mais sentimento, sensibilidade, entrando necessariamente em decadência. Finalmente, os povos se tornariam o que Spengler chamava de "povos de Felás" - Felás são os egípcios de hoje, que tiveram uma grande civilização no passado e hoje, para Spengler, seria um povo morto. É aí que está a questão do Mario de Andrade: a urbanização.

A elite paulista do café, pelas conjunções históricas, teve um momento de crescimento econômico extraordinário em meados do século XIX, num período coincidente com a proibição do tráfico de escravos pela Inglaterra. Dadas as circunstâncias, o trabalho escravo se tornava então uma mão de obra praticamente inviável, levando a oligarquia cafeeira ao abolicionismo.

Procurando achar uma solução que conciliasse o enorme crescimento da produção e a demanda por mão de obra, o café aproveita a crise italiana decorrente da guerra de unificação e passa a incentivar fortemente a imigração italiana para o Brasil. Os italianos vêm, então, aos milhões para São Paulo e mudam o panorama da sociedade brasileira, principalmente paulista. Eles acabam por promover uma certa modernização.

O trabalhador italiano era uma mão de obra livre, não era propriedade a não ser dele mesmo. Esse novo cenário resultou numa liquidez em São Paulo na forma de salário, ou seja, capital variável. Assim, serão os próprios italianos que vão se incumbir de atender as necessidades dessas novas massas trabalhadoras (fábrica de tecidos, sapatos etc.). Isso foi fazendo com que o dinheiro, que na época da escravidão era retido com o senhor, 
saísse do café, fosse para o trabalho, e do trabalhador para a indústria que ia se criando em São Paulo. De modo que São Paulo se industrializa pelo capital que antes era retido nos escravos. É do café, no final das contas, de onde parte o dinheiro que vai financiar a industrialização paulista e o surgimento de uma burguesia industrial (Matarazzos, Crespis e companhia). Ou seja, involuntariamente, o café financia a industrialização a contragosto.

Esse é um ponto muito importante para entender o Modernismo e que, muitas vezes, a crítica não entende: o café se sente roubado pela indústria. Houve até um manifesto anti-industrialista no período. Essa hostilidade à indústria fazia com que o café fosse, ao mesmo tempo, moderno em certos aspectos, mas também profundamente antimoderno, já que a modernidade ocidental parte do éthos da fábrica. Isto é, claro, tomando a industrialização como a base estrutural do moderno.

Se você descer aos costumes da vida cotidiana, café e indústria não se misturavam: esta constrói seus palacetes na Avenida Paulista, e aquele, em Higienópolis. Constitui-se uma disputa de hegemonias dentro de São Paulo, a cidade se transforma numa espécie de campo de batalha - as latas contra o saco de aniagem. O Modernismo se constitui justamente nesse campo. E o Mário de Andrade, que é o grande intelectual a tratar do assunto, verá a industrialização em São Paulo como um momento de uma sociedade rompida no seu íntimo.

O café tem, então, através de Paulo Prado, uma luta com o Brasil e, ao mesmo tempo, uma disputa dentro de São Paulo, com a indústria emergente. Macunaíma é um romance dessas disputas, desses antagonismos. 
O Mário vai centrar-se nas teorias de Spengler de A decadência do Ocidente $(1918)^{5}$ - que no caso é Europa (e um pouco os Estados Unidos) - para a concepção do romance. O que ele concebe em Macunaíma é que os italianos - que são Europa -, ao se transferirem para São Paulo, transferem a decadência do Ocidente para o Brasil. Não por acaso, Venceslau Pietro Pietra uma verdadeira alegoria do carcamano - rouba o futuro do Brasil, a pedra muiraquitã, e São Paulo se transforma numa espécie de prolongamento do Ocidente, decadente pela industrialização.

Os primeiros capítulos do livro basicamente constroem o herói como uma síntese operada por uma consciência paulista de todos os regionalismos e mitologia cultural. Concebe-se ali um herói que poderia fundar uma civilização. O Brasil poderia vir a ser a oitava civilização na História do mundo - conforme essas teorias, só teriam sido civilizações China, Índia, Mesopotâmia, Egito, Grécia, Roma e o Ocidente.

Porém, há um capítulo no qual Macunaíma perde a muiraquitã, que é engolida por uma tracajá (uma tartaruga) pescada por um regatão peruano que, na verdade, é uma caricatura do italiano. Daí em diante, a partir do quinto capítulo, dá-se início a essa disputa extraordinária na construção de uma hipótese de civilização brasileira.

O capítulo quinto, em que Macunaíma chega a São Paulo, é o momento no qual o livro se transforma em romance. Até os quatro primeiros capítulos, ele está no âmbito do folclore, do mito, mas é um mito fake. Já é um mito organizado em um sistema moderno, do romance. De todo modo, ele só se configura plenamente

5 SPENGLER, Oswald. A decadência do Ocidente: esboço de uma morfologia da História Universal. Rio de Janeiro: Zahar, 1973. 
como romance a partir do momento em que Macunaíma passa a ser um anti-herói. Ele é herói até o capítulo quatro, e, quando ele vai para São Paulo para recuperar a muiraquitã, o andamento formal passa a ser de romance. Como se o próprio Macunaíma a possibilidade de uma civilização brasileira - saísse do mundo dele, o do mito, e fosse para a Metrópolis-São Paulo.

A São Paulo de Macunaíma não é real ou verossímil, é uma construção literária em que tudo é máquina: a Metrópolis da tese spengleriana. Macunaíma vê, então, aquela cidade e não a entende, é um mundo desconhecido. No entanto, ele vai encontrando um modo de se adaptar a essa realidade e, nesse processo, perde sua alma. Ou seja, ele é derrotado: a modernidade destrói a possibilidade de o Brasil vir a ser uma civilização porque o Brasil, adaptado ao éthos burguês-industrial, passaria compartilhar a decadência do Ocidente.

Esse complexo literário, dos mais sofisticados, no qual você tem um material de folclore subsumido a um sistema moderno de romance, é um dos grandes momentos da literatura brasileira. Há aí o herói de nossa gente, que não está formado - é um herói sem caráter, apenas uma hipótese, portanto -, em disputa com a modernidade, que é a indústria. $\mathrm{O}$ que mostra que Mário de Andrade (e o Modernismo, de modo geral) tem uma face profundamente antimoderna na medida em que rejeita o grande elemento da modernidade, que é a indústria, e tudo aquilo que a indústria traz: destrói oligarquias, constitui uma burguesia urbana, o proletariado etc. Todo esse pacote ele está rejeitando. Em Macunaíma - que é a grande obra do Modernismo, o resto é quase detalhe - existe a configuração de grandes contradições brasileiras. É isso que o torna grande: há uma modernização antimoderna. 
Fernando Breda: É nesse sentido, então, que Macunaíma e o Modernismo se entroncariam no ideário cafeeiro?

Carlos Berriel: Exatamente, a São Paulo real vivia uma disputa interna de hegemonias. O café desenvolve toda uma ideia de que os italianos eram os estrangeiros negativos. O que se nota mesmo nos jornais da época, que publicavam ideias econômicas antigas de que a única riqueza é a que vem da terra, além de outras coisas assim que foram recauchutadas. Tudo isso para dizer que a burguesia industrial italiana não poderia ir além das chinelas.

Isso, em termos de teoria econômica, é um problema sério. Se formos seguir Marx, só é capitalismo verdadeiro aquela economia em que o capital industrial subordina as demais atividades econômicas - claro, ele está escrevendo isso no século XIX; hoje, é outra história. No Brasil desse período, quem manda é a oligarquia rural, ela é que determina os preços da indústria. A indústria é uma atividade subordinada à agricultura. Nesse sentido, o capitalismo que o café quer não é "pleno". Exatamente uma das questões (a de um capitalismo pleno ou não) que o Brasil nunca resolveu.

Fernando Breda: Chegamos assim, então, num ponto interessante. Uma questão que salta aos olhos é uma defesa do romance como uma espécie de expressão da filosofia da História de Mário de Andrade, tendo como fundo, por sua vez, algumas similitudes com algumas ideias de Paulo Prado e alguns autores alemães. De algum modo, essa filosofia da História guardaria semelhança com outros autores importantes 
do pensamento social brasileiro naquilo que seria uma defesa de uma civilização brasileira própria. Para tanto, Mário teria, então, como pressuposto, que o passado brasileiro já fornecia bases suficientes para criação de uma civilização própria.

Um outro movimento, de outra fração da oligarquia brasileira, centrado na figura de Gilberto Freyre, também pensava algo nesse sentido. Ainda que o passado reivindicado por Freyre não fosse propriamente o mesmo de Mário, o raciocínio guarda semelhanças. Tanto um, como o outro tomavam que não poderia ser descartado o acúmulo de uma longa adaptação geográfica que já teria se realizado historicamente por aqui. Acontece que a crítica que consagrou o Modernismo, não raro, pensa essas figuras em chave quase que contrárias: Freyre conservador e reacionário, Mário modernizante e progressista. Como você vê a inserção do pensamento de Mário de Andrade no campo das "interpretações do Brasil"?

Carlos Berriel: Faz tempo que eu não leio Gilberto Freyre. Do que eu me lembro, ele não teria um projeto nacional. Posso estar enganado, mas na leitura dele, o Nordeste teria constituído uma tradição sólida, inclusive de conciliação entre classes, de tradição cultural original etc. - dentro de perspectivas culturalistas, portanto. Mas a teoria dele de história ficaria muito circunscrita ao mundo do açúcar.

O pensamento de Freyre, até onde lembro, é uma teoria de harmonia social a partir dos elementos tradicionais que foram se acomodando com a natureza e com a História e que a partir desses elementos harmônicos, na opinião dele, já tinha gerado 
uma sociedade muito admirável. Nisso, eu acho que é muito diferente de São Paulo, porque o café veio a constituir os seus projetos em disputa direta, sem harmonizações.

O açúcar foi a atividade econômica hegemônica durante quase 400 anos na história do Brasil, mas, já no começo do século XX, o café representava mais da metade da pauta de exportação do Brasil, chegando a $80 \%$. O açúcar representava, no período da Semana, em torno de um décimo da produção econômica. Daí o romance de José Lins do Rego - Usina (1936), por exemplo sobre a decadência da economia açucareira. $\mathrm{O}$ açúcar se ressente disso e passa a viver do passado, a retratar a decadência. Os romances de José Lins do Rego são de nostalgia, de um mundo que acabou. Gilberto Freyre fala voltado para o passado, não tem ideia de futuro.

Em São Paulo também inventam um passado: aquelas teorias de bandeirantes... a coisa mais fake do mundo. Retrato do Brasil [de Paulo Prado] é modelo de como inventar uma tradição: aquilo nunca existiu, a historiografia atual já liquidou tudo aquilo. Mas a ideologia do baronato do café criava um projeto para o país inteiro. Não era um projeto de igualdade, mas incorporava o país inteiro. Freyre não tem esse alcance.

Fernando Breda: Voltando ao Mário: fiquei com a impressão que há nele um movimento que tenderia ao paradoxo. Por um lado, ele defenderia a existência de uma civilização e cultura local, já com alguma maturidade e capaz de formar e dar feição a uma brasilidade singular. Por outro lado, e ao mesmo tempo, defendia uma ruptura com a tradição local porque era academicista e um tanto anódina. Há nele esse movimento tendente ao paradoxo? 
Carlos Berriel: Há, na verdade, um complexo de paradoxos. O Brasil para ser alguma coisa precisaria encontrar dentro de si os materiais: Macunaíma. Mas ao mesmo tempo, o Brasil (Macunaíma) não é capaz de chegar a um resultado por si mesmo. Macunaíma, por ele mesmo, ficaria lá no mito da floresta. Seria preciso uma inteligência paulista para conduzi-lo, e essa é a organização que o Mário faz: conduzi-lo a um projeto de nação. Ocorre que esse projeto pode ser destruído pela indústria (entenda-se, também, uma certa modernidade), representado alegoricamente por Venceslau Pietro Pietra, o italiano ladrão de pedras, ou seja, ladrão de civilizações.

Então, Macunaíma é composto por contradições da história do Brasil do ponto de vista da oligarquia do café. E Mário de Andrade era um intelectual orgânico do café.

Vamos pensar Macunaíma escrito por outras inteligências. Gilberto Freyre poderia reescrever Macunaíma? Se fosse escrito por Freyre, ele iria para o Nordeste, casaria com a filha de um dono de engenho e ficaria na rede lá, transando com escravas.

Fernando Breda: Por acaso, mal e mal, um pouco o destino de Riobaldo...

Carlos Berriel: Exato. Se Macunaíma fosse escrito por um escritor comunista: esse Macunaíma comunista fundaria um país? Não sei, mas seria interessante. Ele viria para São Paulo, encontraria uma guerrilheira comunista - como está no filme do Joaquim Pedro de Andrade -, viraria comunista, faria uma revolução e nós moraríamos num gulag tropical muito bacana [risos]. 
Então, quais são as consciências que poderiam organizar um projeto nacional a partir de um herói construído pelo material folclórico? Cada um pode fazer uma coisa, Mário de Andrade fez isso. E no caso dele, é muito importante: o romance para na irresolução. Isso, inclusive, dá grandeza a ele.

Fernando Breda: Seria um pouco a formalização desses paradoxos?

Carlos Berriel: Exatamente. Issoémuitoimportante: Macunaíma é um herói que fracassa nos seus objetivos. O romance termina com a constituição do fracasso porque Macunaíma é contaminado pela civilização ocidental, pelo mundo da indústria. Quando ele consegue a muiraquitã de volta, ela já não faz mais sentido para ele e se torna apenas um balangandã no beiço dele. Ele volta para a Amazônia, mas ele já não a entende mais, ele não entendia mais o silêncio.

Por sinal, já na primeira frase do romance se vê isso: "Houve um momento em que o silêncio foi tão grande escutando $o$ murmurejo do Uraricoera, que a índia tapanhumas pariu uma criança feia $[\ldots .$. ". O silêncio é de onde nascem os mitos, o silêncio primordial. Quando Macunaíma volta a ele, já não mais o entende, está ali perdido.

Fernando Breda: Macunaíma seria, então, a formalização de uma derrota e, ao mesmo tempo, de uma disputa que não acabou à medida que o próprio romance se constituiria nessa disputa. 
Carlos Berriel: Há uma disputa em que ele é derrotado, mas há um porém: quando ele morre, ele vira tradição. Como é que a morte dele? A natureza e o mito o destroem. Já perdido e sozinho na "natureza", uma Iara (mitologia brasileira) o chama para dentro d'água, ele se joga para brincar com ela e ela, vingativa, o devora. Ela morde seu beiço, onde está muiraquitã, e tira-lhe uma perna. Ele é destroçado, perde para sempre a muiraquitã, mas não morre. Ele vira tradição: abandona a terra e vai para o campo vasto céu.

O material, a substância de Macunaíma continua aí: ele nasce no campo da tradição/mito e retorna para o campo da tradição ao se tornar a constelação da Ursa Maior, uma constelação do Hemisfério Norte. Pode-se tirar uma série de coisas daí. O importante é que a morte dele não é uma morte total, é como se houvesse a possibilidade do retorno de Macunaíma.

Eu fico admirado com a inteligência do Mário de Andrade de organizar esse material. Eu sou muito entusiasta desse romance; mas apontando para todas essas questões e não ficando nessa bobagem de Modernismo de classe média.

Fernando Breda: Ainda sobre o Mário, queria retomar um pouco da produção artística tardia dele e pensar na peça Café (1933-42), que ele deixou inacabada. Do ponto de vista estético, parece que ali ele vai se aproximando de uma forma de fim de ciclo, com tendência a uma certa aporia que se move em torno de uma revolta social, mas não consegue tomar corpo.

Você defende que a oligarquia cafeeira paulista encampou um projeto nacional que foi, no entanto, de tiro curto. Com a crise de 1929, ocasionada pela quebra da bolsa de Nova York, 
o projeto perdia de vez seu já parco lastro anterior. Em que medida esse naufrágio político se reflete na produção dos artistas do Modernismo, sobretudo em Mário e, mais especificamente, nessa peça inacabada?

Carlos Berriel: Olha, faz tempo que eu não leio o Café e nunca o estudei a fundo também. Eu acho que o grande ponto de partida para falar sobre o Café é que o Mário de Andrade a abandonou. $\mathrm{O}$ fato de ser uma obra inacabada diz muito porque ele não costumava abandonar seus projetos. E não é que ele não teve tempo: ele ainda teve mais de dez anos de vida pela frente, e bastante produtiva. Atuou como historiador da cultura e passou a ser mais institucional, dirigindo o Departamento de Cultura de São Paulo e buscando registrar tradições.

Eu acho muito significativo o fato de ele ter abandonado essa obra de ficção, porque o projeto, de fato, estava morto. O Brasil daquele momento tomava a direção de uma modernidade industrial. A coisa mais próxima de modernidade foi o que veio com Getúlio: de industrializar se aliando, não ao café, mas à burguesia industrial. Aí o projeto do café miou. A peça dele, que é uma espécie de ópera, ficou inacabada, mas valeria muito a pena estudar.

É um trabalho muito interessante, mas é preciso ter uma chave de entrada nessa obra porque o panorama mudou. Uma coisa é quando ele escreve Macunaíma, em 26-28. Em 1933, 1934 dançou o projeto.

Fernando Breda: Uma leitura esquerdizante da peça, da Companhia do Feijão, procurou relacionar a forma algo agônica 
da peça com uma incapacidade da esquerda em dar corpo à revolta ou algo assim.

Carlos Berriel: Bom, essa eu não vi, mas a Companhia do Latão, do Sérgio de Carvalho, montou algo na Unicamp há uns anos e me chamou para conversar sobre a peça. Eu fui lá umas duas, três vezes. Depois quando ele montou, não tinha nada do que eu tinha falado. É a coisa mais difícil do mundo tirar isso da cabeça das pessoas: Mário de Andrade não era de esquerda! E isso não é adjetivo, são configurações ideológicas. Não é critério de valor artístico. O Café é uma peça de perplexidade, de um momento em que o Mário de Andrade via seus referenciais desmoronando.

Fernando Breda: Bom, uma pergunta também sobre o pensamento político de Paulo Prado. Na concepção dele, o que animaria socialmente as aspirações estéticas dos modernistas seria, em parte, uma tentativa de atualização da inteligência brasileira, ou ainda, um acertar de ponteiros do relógio local. O que, na concepção dele, resultaria em um encontro, nacionalmente atualizado e emancipado (claro, na visão dele), com as ideias europeias, diferentemente do que viria ocorrendo então, quando elas entrariam no Brasil já sem vitalidade.

Essa espécie de atualização do relógio local com a Europa é algo muito forte entre intelectuais no Brasil, não só no Modernismo, e tanto à esquerda quanto à direita. Como você vê esses movimentos?

Carlos Berriel: Eu começaria questionando uma afirmação que normalmente as pessoas aceitam de graça e que não deveriam, 


\section{Fernando Breda}

que é "Europa". De que Europa estamos falando? Europa não é uma unidade histórica. Então, quando se fala "vamos acertar o relógio com a Europa", essa frase é muito vaga. Itália é uma Europa, Inglaterra é outra, Portugal é outra...

A referência de Paulo Prado é principalmente Portugal. O intelectual central na cabeça do Paulo Prado chama-se Oliveira Martins, um historiador membro da geração de 1870 de Portugal (junto com Eça de Queiroz, Ramalho Ortigão etc.) e talvez o mais consistente intelectual dessa geração (ainda que não o melhor escritor).

Um intelectual que ganha importância quando Portugal começa a perder suas colônias para Inglaterra - pois em 1889-1890 a Inglaterra "rouba" uma grande parte da África portuguesa. Esse acontecimento é central, inclusive para o Modernismo - procurei demonstrar isso na segunda edição de Tietê, Tejo, Sena (1994). ${ }^{6}$ Moçambique e Angola eram um território só, continuo. No centro, entre Angola e Moçambique, foi descoberto por um aventureiro inglês, Cecil Rhodes, a maior reserva de ouro do mundo na época. Com isso, o governo inglês decreta que ali passa a ser território inglês - dando até o nome de Rodésia em homenagem ao pirata. Então, simplesmente com uma carta, a Inglaterra "rouba" um enorme território no interior da África rico em ouro, e Portugal não tem como resistir.

Isso leva a uma enorme crise do sistema colonial português e o rei Carlos I, amigo de toda geração de 1870 e recém entronizado, nomeia Oliveira Martins para reorganizar as colônias restantes. Diante da crise colonial, o que fazer? O modo como Oliveira Martins concebe uma política (e ele escreve sobre o assunto)

6 BERRIEL, Carlos. Tietê, Tejo, Sena: a obra de Paulo Prado. Campinas: Papirus, 2000. 
para o restante das colônias portuguesas servirá de modelo para o que Paulo Prado vai desenvolver no Retrato do Brasil.

Basicamente, a ideia consiste em que o dominador deve morar no território da colônia. Não mais como antes, em que os portugueses ficavam em Portugal e viviam das rendas que os africanos mandavam para eles. Por isso perderam o Transvaal. Quando Paulo Prado fala de "Europa" está falando de Portugal reorganizando suas colônias. E essa reorganização servirá de modelo para ele pensar o Brasil.

Quando Mário de Andrade fala de "Europa", dependendo do texto, ele está falando de um lugar diferente. Por exemplo, o primeiro livro de fato importante dele, A escrava que não é Isaura (1925), é inteiramente em diálogo com as ideias do futurismo italiano, especialmente com um importante poeta florentino, chamado Ardengo Soffici. O livro é escrito a partir de uma poética de intelectuais florentinos que querem construir uma nova organização do seu país a partir de uma tradição do passado que se toma como modelo de futuro. Porque existem dois futurismos: o milanês do Marinetti, de que o Mário não gostava (que era uma estética de uma modernidade industrial, da máquina) e o futurismo florentino, que tinha um modelo de país no passado, no Renascimento. Diga-se de passagem, tanto os futuristas florentinos quanto os milaneses militaram no partido fascista. $\mathrm{O}$ futurismo italiano foi a expressão de intelectuais que queriam romper em poucos anos com o atraso em que a Itália ficou mergulhada por três séculos.

Em termos poéticos, quando Mário de Andrade organiza suas ideias, é a partir de uma Europa, mas de que Europa? Não é toda a Itália, mas a do grupo florentino do futurismo italiano. 
Já em termos de teoria da história, qual a Europa do Mário? Alemanha, e mais especificamente, o pensamento conservador do período de Weimar - onde, inclusive, estava se gestando o ovo da serpente. Onde é que o Spengler foi parar? No Mein $\boldsymbol{k a m p f}$ (1925) de Hitler.

Então quando se fala, "vamos nos atualizar com a Europa", é importante saber qual Europa. Portanto, o Modernismo quando fala de "Europa", nunca foi a Inglaterra, país de capitalismo resolvido: sempre são países de capitalismo atrasado, países que "perderam o bonde da História" na época do Renascimento e "ficaram para trás". São esses os modelos que os modernistas têm: países que precisam resolver o seu capitalismo.

Fernando Breda: Saindo um pouco de Mário para falar de Oswald de Andrade. Você chegou a comentar em outra entrevista de uma certa fissura no Modernismo que se daria pela figura de Oswald. Em que medida essa cisão se reflete na obra dele em relação a seus pares de movimento? Se possível, eu diria para pensar essas diferenças no período em que ele foi mais próximo dos demais modernistas e no período de sua ruptura com o movimento.

Carlos Berriel: Oswald é um personagem extremamente interessante. É bom a gente não parar muito nas questões biográficas que complicam muito. Mas, enfim, em termos de origem básica, a mãe dele era do café, das grandes famílias do café, e o pai já era de uma burguesia urbana, mais moderna, ligada aos grandes projetos de urbanização de São Paulo. Portanto, a origem dele já não é só café, mas também essa elite mais moderna. 
Oswald começa muito conservador, ligado a Washington Luiz, que foi padrinho de casamento dele. Tinha ligação com as oligarquias, portanto. Depois, a partir do momento em que a oligarquia do café vai à falência, ele busca encontrar uma caixa de ressonância nos setores não oligárquicos, que é quando ele se liga ao Partido Comunista.

E a trajetória dele dentro do PC, que eu saiba, nunca foi, de fato, muito elaborada e pesquisada. O PC era uma organização bastante complexa internamente. Tinha, digamos, um centro de poder que era muito ligado às ordens da União Soviética: seguiam os manuais etc., o que fazia com que o partido comunista tivesse uma relação com a realidade às vezes meio duvidosa. Por outro lado, também organizou massas, sindicatos, constituindose como uma força política importante.

Aquilo que o Oswald diz no prefácio ao Serafim Ponte Grande (1933), que ele queria ser um casaca de ferro do proletariado, expressão hoje em desuso, quer dizer o seguinte: ele era o cara de terno e gravata que poderia falar com setores aos quais o proletariado não chegava. Ele se coloca, então, na posição de emprestar ao proletariado revolucionário o seu trânsito entre as elites.

Eu soube, através de conversas com pessoas antigas, que o Prestes não dava muita importância a Oswald. Inclusive, havia até um certo deboche dentro do Partido com relação a ele. Duas pessoas me contaram isso: a viúva do Graciliano Ramos e Ledo Ivo. Portanto, quem pensa que o Oswald teve uma participação importante tem uma visão completamente de fora, acadêmica, idealizada. Ele não era levado a sério, o que eu acho que até pega mal para o próprio Partido Comunista. 
Retomando então: ele chega ao Partido Comunista, porém não mudou de ideia. Qual o pensamento do Oswald? A antropofagia. Se quiser encontrar Oswald de Andrade, você lê o Manifesto antropófago, que é de 1928. Lá está o coração, a mente e a alma do Oswald de Andrade. Quando ele entrou para o PC, ele continuava antropófago.

E a filiação dele não durou pouco, uns 15 anos mais ou menos. Ele tentou escrever romances proletários, mas não funcionou. Quem funcionou foi Jorge Amado - ainda que seus personagens não fossem exatamente proletários, mas do lumpesinato. Oswald tenta encontrar um personagem para entrar no mundo socialista, mas ele apenas conhece um pouco o marginal, que não é a mesma coisa: Marco zero (1943)... ninguém leu aquilo na época.

A questão central é que ele nunca desistiu da antropofagia, que é muito interessante e também paradoxal. Abase da teoria é também Spengler: a ideia de decadência e de que cultura gera civilização. E a batalha dele era para construir uma civilização brasileira a partir dos elementos nacionais, que seriam constituídos a partir do momento em que os índios Caetés devoraram o Bispo Sardinha, daí a antropofagia.

Ou seja, a ideia de que você tem o elemento europeu que, devorado, se transforma num elemento nacional. Mas o elemento nacional precisaria, por sua vez, do fermento europeu: o índio intocado não geraria uma nação, um país - claro, o pensamento dele é muito contraditório. Seria a partir do momento que o nacional deglute o elemento europeu que o fermento da constituição de um complexo nacional se realizaria. 
Fernando Breda: Isso teria relação com a oligarquia cafeeira?

Carlos Berriel: $\mathrm{Eu}$ acho que não. Eu acho que o Oswald nasce ali, mas tem referências que o vão expulsando daquele circuito Paulo Prado-Mário de Andrade - que, aliás, romperam pessoalmente com ele, mas por outros motivos.

Depois que ele sai do PC, em 1945, ele vai para a direita. Já ali em 1946, 1947, ele está próximo de movimentos ligados à Guerra Fria, aos movimentos estimulados pela CIA, basicamente. Não que ele fosse agente ou algo do tipo - claro, isto é bobagem. De todo modo, a CIA atuava muito em uma série de movimentos no imediato pós-guerra por meio de coisas como a defesa [abstrata] da democracia e um monte de bobagens do tipo, e ele entrou nessa. Tudo isso está documentado, são palestras escritas por ele.

Depois disso, ele começa a fazer conferências em coisas como "liga de senhoras" e afins. Ele fica perdido mesmo. Tentou ser professor na USP, quando escreveu aquele livro sobre utopias no novo mundo, que é uma teoria da antropofagia requentada. $\mathrm{E}$ que acabou não dando certo.

Talvez eu tenha me perdido um pouco nos aspectos biográficos, mas o essencial é isso: Oswald é antropofagia. Quando ele sai daí, ele se perde, vai perdendo o foco.

Fernando Breda: Ainda pensando na associação de classe que o senhor procura fazer entre o Modernismo e a oligarquia cafeeira, parece-me que tem embutido aí uma espécie de distinção entre uma "elite fazendão versus elite industrial-modernizante", com alguma vantagem para a segunda - esta seria indutora de um 
capitalismo verdadeiro, para ficarmos nos termos do Marx.

Tenho para mim que o tempo provou que essa distinção não é lá muito factível no caso brasileiro. A crença numa possível função civilizadora e/ou integradora da fração industrial de nossa burguesia nacional teria algo de uma ilusão que já não se ajusta: a opção foi, e continua a ser, pelo subcapitalismo. Na crítica que você faz a uma certa fraqueza do projeto dessa oligarquia, não teria ainda uma crença em abstrato no progresso ou mesmo em um horizonte histórico de uma revolução burguesa no Brasil ou algo do tipo?

Carlos Berriel: Eu não sei se eu entendi bem a questão. Você está colocando, centralmente, a questão de um projeto nacional, é isso?

Fernando Breda: Mais ou menos... Nos seus textos, parece que há uma comparação entre o baronato do café e uma burguesia industrial que seria indutora de um capitalismo verdadeiro. Entre elas, parece que essa burguesia industrial leva vantagem na sua avaliação. Eu fico me perguntando se, hoje, passado tudo o que se passou, essa crença numa suposta vantagem, por assim dizer, da indústria não tem se demonstrado já superada pela própria História - especialmente no Brasil. Digo isso no sentido de que uma suposta aliança com a burguesia nacional industrializante, na hora do "vamos ver", sempre desemboca na opção pelo subcapitalismo.

Carlos Berriel: Tudo que vim falando até aqui, foi um pouco como, digamos assim, um historiador. Algo que seria "neutro". 
O que, na verdade, sabemos que não existe.

De 1990 para cá, é muito difícil a gente usar esses parâmetros. O mundo mudou, o Brasil mudou. Mas acho que o Brasil tem alguns momentos de projeto nacional. E esses momentos são muito férteis, inclusive culturalmente; mesmo que nunca dê muito certo.

Eu identifico alguns momentos de projeto nacional. $\mathrm{O}$ primeiro deles seria o período regencial, dos anos 1830 até meados dos anos 1840. Momento, inclusive, em que surge o Romantismo, que faz parte de um projeto estético nacional. Aquele foi um momento muito fértil do país e também um momento em que as rebeliões localistas foram duramente reprimidas. No período de Dom Pedro II, houve uma continuidade: o país definiu um certo perfil, dentro de suas contradições, que são formalizadas melhor do que ninguém por Machado, já no período final do Império e começo da República.

O Modernismo foi um projeto nacional que, na verdade, era um projeto regional e oligárquico sobre o país.

Acho que o grande nome que tentou um projeto nacional foi Getúlio, que assumiu a ideia de transformar o país numa organização nacional apoiada pelo substrato industrial moderno, que superaria - eu coloquei aqui no condicional - os regionalismos. E esse projeto getulista tinha uma boa dose de violência porque senão não se fazia. De todo modo, o projeto nacional do Getúlio foi o mais consistente... e deu no que deu.

Mas, veja bem, quando Getúlio percebia que a burguesia brasileira não estava à altura - por mais que ele tentasse enormemente repassar recursos para alavancar uma indústria ele criava estatais. $\mathrm{O}$ que ele queria era uma indústria nacional, 
principalmente na década de 1950 (quando ele é eleito), até ser derrubado em 1954. Em 1945, Getúlio foi derrubado apesar do enorme crescimento que o Brasil teve durante a Segunda Guerra Mundial. O Brasil ganhou muito dinheiro na guerra e tinha capital para financiar uma indústria nacional de ponta. Quem veio depois, Café Filho, em vez de montar uma indústria automobilística, que era o que estava na ponta da agulha, torrou o dinheiro comprando carro pronto, aquela sucata de guerra. Enfim, dissipou o capital.

Quando Getúlio volta em 1950, eleito, sabia que não podia contar com essa burguesia, então ele transforma o Estado em burguesia, que são as estatais. O que o Fernando Henrique colocou como a primeira missão dele? Se desfazer das estatais. O papo da modernização, mas com indústria estrangeira.

Então, de fato, você tem razão: o Brasil tem uma burguesia, na melhor das hipóteses, de segunda categoria. O que seria uma burguesia de primeira categoria? Uma que diz "quero o meu país para mim, só eu vou explorar, não quero ninguém aqui”. Como foi nos Estados Unidos, Inglaterra, França, etc. O Getúlio queria ir nessa direção; conseguiu um tanto, mas não muito.

Fernando Breda: Não sei se era exatamente isso, mas tangencialmente, sim. Para não perder o ponto: é interessante isso que você fala, porque hoje a gente vive um projeto nacional... ou melhor, não vivemos um projeto nem à direita nem à esquerda: o que se vê no poder hoje é apenas um projeto massivo de acumulação primitiva.

Digo isso porque o Modernismo foi abraçado pela esquerda, sem que fosse levada em consideração possíveis relações com 
um projeto de país conservador, racista e reacionário da elite cafeeira. No entanto, ainda que com várias contradições, no Modernismo, havia uma defesa, ou no mínimo, uma posição "totêmica" que seja, de elementos locais importantes - e aqui cito o Manifesto da poesia pau-brasil: "aos Bárbaros, crédulos, pitorescos e meigos. Leitores de jornais. Pau-Brasil. A floresta e a escola. O Museu Nacional. A cozinha, o minério e a dança. A vegetação. Pau-Brasil [...]". Como você enxerga as novas leituras que vêm sendo feitas do Modernismo, que procuram recuperar do movimento (com alguma positividade) a defesa de outras modernidades possíveis - e aqui penso na questão ecológica e indígena, por exemplo - não propriamente ligadas ao progresso e/ou ao capitalismo verdadeiro? Ou justamente por não se colarem a esse capitalismo verdadeiro.

Carlos Berriel: Eu acompanho pouco, na verdade. De todo modo, você levanta uma série de questões extremamente importantes. Nós, basicamente, estamos no meio de uma encruzilhada e não sabemos que caminho tomar. Os projetos foram desfeitos e alguns se revelaram irrealistas. Eu acho que nós não temos um projeto nacional e nem sei mais se, a essa altura dos fatos do mundo, podemos colocar a questão da nação. Então, pareceme que nós estamos remoendo ideias que muitas vezes têm cem anos e que foram derrotadas. Estamos tão perdidos que um sujeito desqualificado como Bolsonaro conseguiu convencer grande parte da população que tinha um projeto para o país, que seria ainda mais espancar, sequestrar, mentir.

Eu acho que nós estamos vivendo um momento de fracasso social e político de praticamente todas as propostas. O projeto 
de globalização deu numa tragédia universal - aí vai o PSDB, ligado à questão da globalização. Quando eu vejo uma esquerda mais tradicional falando do movimento sindical, parece-me que é utopia no sentido vulgar. O capital destruiu o socialismo como projeto - pelo menos no momento atual, no futuro espero que não - investindo em tecnologia, quebrando os sindicatos e o movimento operário.

Nós vivemos um momento de fracasso generalizado. Tanto assim que para se pensar o mundo atual, muitas vezes volta-se à época em que de fato havia projetos: o próprio Modernismo e sua celebração estão nesse quadro. São mundos subterrâneos, arqueológicos a essa altura do campeonato. Vivemos um momento de grande perplexidade e será preciso que surjam novas ideias. Mas todos os movimentos que existiram no século XX fracassaram em parte ou completamente.

Fernando Breda: Agora, indo mais ao campo da crítica. Outro aspecto que acho valioso de seus trabalhos é a visão de que a historiografia do Modernismo optou, entre a verdade e a lenda, pela lenda. Sem querer entrar no mérito da veracidade, pareceme que uma certa visão lendária-celebratória, por assim dizer, do Modernismo é, em boa medida, resultante do fato de que a historiografia e mesmo a crítica a respeito das obras foram produzidas por eles mesmos ou seus herdeiros, não é mesmo?

Quanto a isso, eu acho que um bom elemento a se pensar é Antonio Candido. Até onde entendo, a atuação do crítico foi fundamental à consolidação canônica do Modernismo paulista e mesmo da imagem do movimento como uma explosão criadora que se instaura com a Semana de 1922. Algo que pode ser visto, 
por exemplo, no texto Literatura e cultura de 1900 a 1945, onde ele recupera uma noção que já se encontrava esboçada nos trabalhos de Mário de Andrade de valorização da especificidade da cultura local no trato com a europeia, mediante a "libertação de uma série de recalques históricos, sociais, étnicos, que são trazidos triunfalmente à tona da consciência literária [...]”.

E isso seria - e aqui é onde quero chegar - o que definiria a originalidade do Modernismo - e conformaria também uma espécie de critério até mesmo para a maturidade alcançada por Machado, tal como aparece na Formação da literatura brasileira (1959). No mais, o próprio Antonio Candido já afirmou em depoimentos que seria tributário da geração de 1920. Visto isso: qual o lugar que Candido ocuparia nessa historiografia? Ele seria uma espécie de faceta modernista na crítica literária? Ou ainda, de que maneira você relaciona o trabalho de Candido com o Modernismo?

Carlos Berriel: Essa é uma questão muito importante, e eu não sei se eu vou dar uma resposta satisfatória. O livro mais importante do Antonio Candido é a Formação da literatura brasileira. Nesse livro ele olha para trás, para a história do Brasil, e localiza um percurso através das obras, em que o Brasil vai gradativamente se tornando objeto da literatura. Objeto da literatura não apenas como tema, mas também como forma expressional. O olhar dele é do presente para o passado, mas há pessoas que dizem que é do passado para o futuro: como se Tomás Antônio Gonzaga já visualizasse Machado de Assis lá na frente. Isso é má fé. Ele tem uma visão do presente, do final dos anos 1950, olhando para trás, identificando elementos de 
surgimento de formas expressionais e de temáticas nacionais. Nesse processo surge uma nação literária: o Brasil passa a existir como literatura.

Depois, nos estudos sobre o Modernismo - que não estão na Formação -, ele vê no Modernismo - especialmente em Mário de Andrade - o momento em que a produção literária vem casada com uma consciência crítica, que estaria muito fraca em Alencar, por exemplo. Uma consciência que alcançaria uma espécie de apogeu no Modernismo, em que os autores não só compunham obras brasileiras, como tinham consciência do que estavam fazendo. Essa, me parece, é a tese dele: a ideia de que o Brasil existe como literatura e na literatura.

Antonio Candido se constituiu numa baliza da história brasileira, em que você tem que discutir com ele, para concordar, discordar, acrescentar, retirar. Ele é uma referência. Não vejo muito futuro em alguém negar a obra dele in totum.

Quando eu publiquei meu trabalho sobre Paulo Prado, imediatamente enviei para ele. E ele me disse que eu tinha razão. Eu entrei dentro do Modernismo e não neguei a tese dele - até uso como epígrafe uma frase de sua autoria -, mas eu encontrei dentro do Modernismo uma série de contradições que ele não negava, mas que também não tinha analisado.

O Modernismo foi apresentado por ele como movimento nas suas linhas gerais, a chamada linhas de força (o que em pintura são aquelas linhas de pincel que delimitam o objeto). O que eu fiz dentro desse campo foi encontrar as contradições. Paulo Prado, Mário de Andrade, Oswald procuraram interpretar o Brasil? Sim, porém dentro de um quadro de contradições que 
eu procurei localizar. Aí é um pouco como eu penso as coisas: é preciso localizar a classe social. Ninguém é inocente, todos se ligaram a uma classe. Isso se chama chão social.

Fernando Breda: Quero insistir num ponto. Conforme você disse, ele situa um quadro do Modernismo e você pensou as contradições e chão histórico desse quadro. Mas queria pensar em continuidades possíveis. Por exemplo, quando ele fala da USP, ele comenta como um projeto de criação da oligarquia derrotada. Não quero colocar que o Modernismo continuaria pura e simplesmente em Antonio Candido. Mas, indo mais direto ao ponto: qual a continuidade que existe entre ele e o Modernismo e em que chão histórico ele está situado nesse sentido.

Carlos Berriel: Eu não sei responder, mas acho que Antonio Candido ficou muito encantado com o fato de Mário de Andrade tentar pensar o país como um todo e, ao mesmo tempo, insinuar um projeto nacional. Não por acaso, Mário de Andrade, quando compõe Macunaíma, escreve uma dedicatória para duas pessoas: José de Alencar, "que vive no campo vasto do céu" isto é, na tradição - e a Paulo Prado. Depois ele tira José de Alencar na edição que ficou definitiva.

Veja, o José de Alencar também tentou criar uma literatura nacional, mas em um sentido diferente do que o que está em Macunaíma. Se você abre o mapa do Brasil, pega as obras de José de Alencar e põe em cima dos estados, há: Iracema (1865), Ceará; As minas de prata (1865), Minas Gerais; Senhora (1875), Rio de Janeiro; O tronco de Ipê (1871), Rio Grande do Sul. Ele tentou fazer um mapa do Brasil, porém ele não superou 
- o que é da época - os regionalismos. Em Macunaíma, você tem uma espécie de tentativa de superação dos regionalismos a partir de um gesto bastante mágico de fazer tudo convergir para um só personagem, que vai encontrar o seu destino em São Paulo.

Em Alencar, ainda, há um artificialismo expressional, que em Macunaíma é superado por um realismo linguístico cru, cheio de cacófatos, frases feitas. Essa assunção, inclusive da nossa feiura, da nossa sujeira, da nossa boca suja, do que constituía à época o tecido social brasileiro, é muito encantadora.

Eu acho que o Antônio Cândido parte muito daí: se o Brasil existir - e não pode ser idealizado -, você pode olhar ao passado e ver como se conduziu a isso. Há uma matéria que caminha e converge em direção a Macunaíma.

Fernando Breda: Também a Formação caminha, passa por Machado, e, tenho impressão, desemboca virtualmente no Modernismo. No mais, a própria Formação é também uma tentativa de síntese brasileira.

Carlos Berriel: Roberto Schwarz, quando estuda Machado, tenta ver uma herança da literatura brasileira anterior. O normal era jogar direto a literatura machadiana na Europa. Roberto tentou ver o quanto de literatura brasileira, principalmente Alencar, estava em Machado. Ou seja, não tirar o Machado da trajetória que tinha sido localizada por Candido.

Ele vê, por exemplo, na presença dos pobres um elemento nacional importante: os pobres como personagens. Ele mostra que em Alencar os personagens pobres são secundários, mas 
existem. $\mathrm{O}$ holofote fica em cima de personagens artificiais, ao passo que os personagens do fundo, esses são de fato brasileiros. E o que Machado fez foi ignorar o holofote e focar no que ninguém falava. Eu acho que Roberto faz esse movimento de colocar Machado dentro da tradição literária brasileira. O que é um grande feito, mas em chave negativa.

Mesmo a elite brasileira como negativa é um retrato realista. $\mathrm{O}$ Peri de Alencar, por exemplo: Mário de Andrade disse "matemos Peri”. Macunaíma é também um índio, mas é outra coisa com relação a Peri. Então, há um movimento de constituir personagens que matam a idealização que impedia que víssemos o nacional. Como se fosse preciso matar os personagens positivos para que o nacional aparecesse.

Enquanto a gente olhar latifundiário escravocrata como positivo, não vamos a lugar nenhum.

Fernando Breda: Passados mais de trinta anos de seus estudos sobre Modernismo, as disputas quanto às leituras do movimento se mantêm. Como você avalia essa disputa na qual você se meteu, e em que pé que ela está hoje, à beira do centenário da Semana de 22 ?

Carlos Berriel: Ainda garoto, eu fiquei muito encantado com o Modernismo. Eu li Macunaíma numa época em que era uma obra rara. Ninguém tinha, não circulava, ninguém lia. $\mathrm{O}$ Modernismo quase tinha morrido. Ele foi ressuscitado no final dos anos 1960.

$\mathrm{Eu}$ fui fazer faculdade, Filosofia e Ciências Sociais. Havia um professor que tinha um projeto de estudar o pensamento 
brasileiro e me convidou para realizar um estudo com o grupo. Quando ele me convidou para integrar o grupo de estudos, eu já vinha lendo Mário de Andrade e tinha alguma ideia de que ali havia uma unidade central de elementos tradicionais que se mesclavam de modo interessante com o que havia de mais novo. Eu fiz o projeto para estudar Mário de Andrade a partir de um centro organizador: uma dialética entre o velho e o novo. E tinha aí uma influência do tropicalismo que também conjugava tudo isso. Eu estava muito ligado nessas coisas.

À medida que eu fui aprofundando, foi aparecendo - não era um pressuposto - ao longo da leitura a relação dele com a oligarquia do café e com as teorias que ele leu. E eu fui nessa direção.

Em 1978, eu publiquei na Folha um artigo sobre o aspecto hostil do Mário de Andrade à indústria: chamava A odisséia antiindustrialista. À época comemoravam-se 50 anos da publicação de Macunaíma. Nisso, eu resolvi fazer uma pós-graduação em Literatura em 1981. Roberto Schwarz me acolheu como orientando. Na defesa, as vinculações que eu mostrava do Mário com um pensamento muito conservador não pegaram bem. Mas é importante ter em mente que eu cheguei nas ideias que tenho sobre Mário de Andrade não como ponto de partida, mas de chegada. Eu não procurei nem fazer elogio, nem derrisão. Mas não era o que se dizia, que o Mário era de esquerda. Eu adoraria, mas ele não era.

Nesse processo, foi ficando evidente a extrema importância que Paulo Prado tinha para ele. Retrato do Brasil e Macunaíma são obras que caminham muito juntas. Eu fui olhar o Paulo Prado e não tinha nenhum estudo sobre ele. E vi que ali estava um pensador muito importante e eu me pus a estudá-lo no doutorado. 
Não é que não se falava dele, mas o que se falava dele era inteiramente errado: um ricaço bobo que pagava a conta e ficava atrás dos modernistas em festa. Uma imagem tola que está, por exemplo, no filme $\mathbf{O}$ Homem do Pau-brasil, do Joaquim Pedro de Andrade.

E foi difícil estudá-lo porque ele não dá pistas. Foi um trabalho muito grande, pois quando eu cheguei no Paulo Prado, ainda era forte a ideia de que os modernistas rejeitavam Portugal. E fui vendo em Paulo Prado que ele era bastante dependente intelectualmente da geração de 1870 , que, por sua vez, falava mal de Portugal. Então, quando os modernistas falam mal de Portugal estão imitando os portugueses da geração de 1870, que é totalmente crítica.

$\mathrm{Eu}$ apenas constatei que as coisas eram assim. Lendo esses autores e deixando de forma muito secundária os intérpretes deles, fui vendo o que essas obras me diziam, sem julgá-las. Eu não julgo Paulo Prado nos trabalhos. Eu acho ele um sujeito horroroso, mas tratei a obra dele com o maior respeito. Aliás, eu o tirei do lugar do tolo que paga a conta e o elevei a um intelectual orgânico de uma elite brasileira que quer o país para si. Mas rolou hostilidade, até hoje rola.

Eu tinha na época as minhas ilusões juvenis: achava que estava escrevendo um trabalho pelo qual a esquerda iria se interessar. Ledo engano. Eu fiz inimigos à direita, e a esquerda não deu a menor importância.

Agora, terminado esses dois trabalhos, cheguei à conclusão - na verdade, mesmo antes - de que eu já tinha dito sobre o Modernismo o que tinha a dizer. Eu não queria ser um profissional do Modernismo. Mais ou menos quinze dias depois da minha 
defesa, eu já estava na Itália estudando o Renascimento, campo para o qual me mudei completamente.

Fernando Breda: Mas, bem ou mal, acabou se configurando na própria Unicamp um local que agrega leituras alternativas do Modernismo, né?

Carlos Berriel: Sim, há uma verdadeira liberdade de cátedra na Unicamp. No Rio Grande do Sul também o Modernismo é estudado fora do cânone, e imagino que no Rio de Janeiro também. Eu acho que os estudos sobre o Modernismo ou tomam um caminho crítico ou vão esclerosar. Não dá mais para ficar fazendo aquelas apologias, né? Isso foi um momento acadêmico dos anos 1970 e 1980, mas tem gente que faz carreira em cima disso. Eu acho que o Modernismo tem muito campo pela frente para ser investigado, desde que fora do academicismo chapa branca.

Ocorre também que os estudos críticos do Modernismo, fora do mainstream, não formaram uma corrente, estão dispersos. Enquanto os estudos canônicos do Modernismo formaram uma instituição, a vertente mais crítica não se aglutinou. Eu fiz o meu trabalho, ficou lá, outro está fazendo não sei onde, mas todos muito temerosos porque a blitz é violenta. Eu acho que a gente avançaria muito no entendimento desse país se saísse dessa coisa tão burocrática e chapa branca. Aquilo que falavam da Academia Brasileira de Letras, eles próprios se tornaram.

Recebido em: 15/08/2021//Aceito em 11/09/2021. 